\title{
The unknown underworld: Understanding soil health in South Africa
}

AUTHORS:

Schalk v.d.M. Louw ${ }^{1}$

John R.U. Wilson 2,3

Charlene Janion ${ }^{3}$

Ruan Veldtman ${ }^{2,4}$

Sarah J. Davies ${ }^{3}$

Matthew Addison ${ }^{4,5}$

\section{AFFILIATIONS:}

${ }^{1}$ Department of Zoology and Entomology, University of the Free State, Bloemfontein, South Africa

${ }^{2}$ South African National Biodiversity Institute, Kirstenbosch National Botanical Gardens, Cape Town, South Africa

${ }^{3}$ Centre for Invasion Biology, Department of Botany and

Zoology, Stellenbosch University, Stellenbosch, South Africa

${ }^{4}$ Department of Conservation Ecology and Entomology, Stellenbosch University, Stellenbosch, South Africa ${ }^{5}$ Hortgro Science, Stellenbosch, South Africa

\section{CORRESPONDENCE TO: Schalk Louw}

EMAIL:

louws@ufs.ac.za

\section{POSTAL ADDRESS:}

Department of Zoology and Entomology, University of the Free Sate, P0 Box 339, Bloemfontein 9300, South Africa

\section{KEYWORDS:}

soil signature; edaphic factors; sustainability; food security; sustainable agriculture

\section{HOW TO CITE:}

Louw SvdM, Wilson JRU, Janion C, Veldtman R, Davies SJ, Addison M. The unknown underworld: Understanding soil health in South Africa. S Afr J Sci. 2014;110(5/6), Art. \#a0064, 4 pages. http://dx.doi.org/10.1590/ sajs.2014/a0064

(C) 2014. The Authors. Published under a Creative Commons Attribution Licence.
The need to provide food security to a growing human population in the face of global threats such as climate change, land transformation, invasive species and pollution ${ }^{1}$ is placing increasing pressure on South African soils. South Africa is losing an estimated $300-400$ million tonnes of soil annually ${ }^{2}$, while soil degradation is a major threat to agricultural sustainability ${ }^{3}$. In spite of these problems, treatment of soil health in biodiversity assessment and planning in South Africa has been rudimentary to date. ${ }^{4,5}$

\section{Defining soil health}

Soil is a crucial component of the pedosphere, which sustains life, and should therefore be regarded as one of the most important assets held by South Africans. However, in South Africa, soil is a highly neglected research focus in ecosystem service delivery. Studies of ecosystem services often focus on more elegant and tractable systems, such as pollination networks. ${ }^{6}$ Currently in South Africa, soils are viewed in certain sectors as resources that can be used to generate short-term gains, rather than assets to be protected and developed. Soils form the basis for food security through agriculture, where processes taking place in the pedosphere result in water retention, nutrient augmentation and soil biodiversity proliferation.

In an effort to facilitate research on soil health, or at least stimulate debate on the topic, we propose that soil health be measured by a combination of abiotic (A) and biotic (B) and socio-economic (S) aspects relative to a benchmark measure, i.e.

Soil health $=\frac{\sum \mathrm{A} \cdot \Sigma \mathrm{B} \cdot \Sigma \mathrm{S}}{\text { benchmark }}$

where $A$ is measured by a subset of soil physicochemical indicators (with subsets determined on the basis of variable thresholds relating to soil type and soil usage); B is determined by standard biodiversity metrics (e.g. species richness, abundance, network or species assemblage connectedness), incorporating biodiversity in the context of applied strategies (e.g. agricultural push-pull systems and mixed cropping) and $S$ is determined by socio-economic values (e.g. monetary value, equity, human well-being). In order to scale each component, benchmark values will also have to be determined that will serve as the denominator for calculation of changing component values over time. ${ }^{7,8}$

Here we use a similar model to that used in above ground environmental analyses (e.g. the IUCN's system analysis in Leverington et al. ${ }^{9}$ ), but we recognise that the below ground 'closed' medium functions at different tempos and scales. As such, this model is simplistic, yet a degree of ignorance exists about 'understanding' soils, ${ }^{10}$ strengthening the notion that soils need to be elevated to mainstream research foci where interactions among the physical, chemical and biological components of soils receive precedence and serve as a point of departure.

For soils to operate in a complex, interacting total system manner, biodiversity in different environments serving different socio-economic requirements can potentially be temporally and spatially separated, e.g. hydroponic farms and conservation areas or an ecological network in which all aspects are incorporated. In some cases this can lead to an overall greater soil health set-up than if all elements were combined in one area at a specific time period (e.g. debate on conservation versus agriculture, or conservation and agriculture ${ }^{11}$ and landscape-scale analysis over seasons $\left.{ }^{12}\right)$.

The three components of soil defined here all contribute to ecosystem services and intersect to provide healthy soils. The model for this soil health index (Figure 1), supported by intersection descriptions and more detailed relevant examples (Figure 2), serves to emphasise that soils are extremely complex and function in multiple roles, and as such have a pivotal role in ecological function. Based on this framework, we formulated several key research questions (Table 1).

\section{The need for foundational work on soil organisms}

In the last decade, the diverse roles of soil communities in the ecological function of soils has gained global recognition. ${ }^{13}$ Several large multidisciplinary projects in Europe (such as ENVASSO and EcoFINDERS) now focus on soil organisms using holistic approaches incorporating traditional taxonomy ${ }^{14}$ and modern molecular techniques ${ }^{15}$. However, in South Africa, like elsewhere in the world, research in the field of soil biology has been neglected compared with research in soil chemistry or soil physics. This scenario has started to change over the past decade or two and South Africa is no exception in this regard. Research on a broad biological basis regarding South African soils has increased since the mid-1990s and these outcomes are published in journals such as the European Journal of Soil Science, Soil Biology and Biochemistry, Biogeochemistry, Soil Research, Geoderma and the South African Journal of Plant and Soil. Sadly, however, this cannot be said of pure foundational research on soil organisms and, despite some notable pioneering experts (e.g. Lawrenc $\left.{ }^{16}\right)$, our knowledge of South African soil organisms is largely restricted to taxonomically well-known groups such as ant ${ }^{17-19}$ and spiders ${ }^{20}$, and even then this knowledge is often fragmented and poorly documented. The need to integrate existing research initiatives was unanimously expressed at a Soil Health Workshop at the XVII Congress of the Entomological Society of Southern Africa in July 2011. This expression led to the formation of SERG (Soil Ecosystem Research Group) - a soil biodiversity research group that provides a platform for linking and promoting research on soil organisms. 


\begin{tabular}{|c|c|c|c|}
\hline Conceptual model & Area & Definition & Examples \\
\hline & $A \cap B \cap S$ & $\begin{array}{l}\text { Happy healthy soils - production landscapes } \\
\text { where the inputs are minimal and biodiversity } \\
\text { is maintained through sustained soil ecosystem } \\
\text { service delivery }\end{array}$ & $\begin{array}{l}\text { - Sustainable flower harvesting from the wild } \\
\text { (Figure 2) } \\
\text { - Mixed cropping system with conservation tillage }\end{array}$ \\
\hline & $A \cap B$ & $\begin{array}{l}\text { Ecological function - natural ecosystems with } \\
\text { significant functional roles. Ecological processes } \\
\text { and physicochemical cycles are maintained; soil } \\
\text { condition is preserved }\end{array}$ & $\begin{array}{l}\text { - Wetlands } \\
\text { - Unfarmed Succulent Karoo ecosystems - } \\
\text { dry low primary productivity regions with } \\
\text { low or no animal stocking (Figure 2) }\end{array}$ \\
\hline & $B \cap S$ & $\begin{array}{l}\text { Beneficial organisms - soil organisms are used } \\
\text { by humans for utilitarian purposes }\end{array}$ & $\begin{array}{l}\text { - Biological control (e.g. entomo-pathogenic } \\
\text { nematodes) and vermi-composting } \\
\text { - Bio-prospecting }\end{array}$ \\
\hline & $A \cap S$ & $\begin{array}{l}\text { Input production - production systems } \\
\text { where physical and chemical properties are } \\
\text { manipulated to maintain production }\end{array}$ & - Mono-cultural intensive agriculture \\
\hline $\begin{array}{l}\text {-econo } \\
\text { (S) }\end{array}$ & B & $\begin{array}{l}\text { Biotic - soil biodiversity, including organisms } \\
\text { of all different taxonomic and functional groups, } \\
\text { which together result in multi-trophic interactions }\end{array}$ & - Maputo-Pondoland Centre of Endemism \\
\hline & A & Abiotic - physical and chemical properties of soil & - Iron oxide rich Kalahari sandy soils \\
\hline & S & $\begin{array}{l}\text { Socio-economic - encompasses ownership and } \\
\text { land use and subsequent production }\end{array}$ & - Hydroponics (Figure 2) \\
\hline
\end{tabular}

Figure 1: Proposed conceptual scheme for defining soil. We consider healthy soils as those that provide abiotic, biotic and socio-economic services.

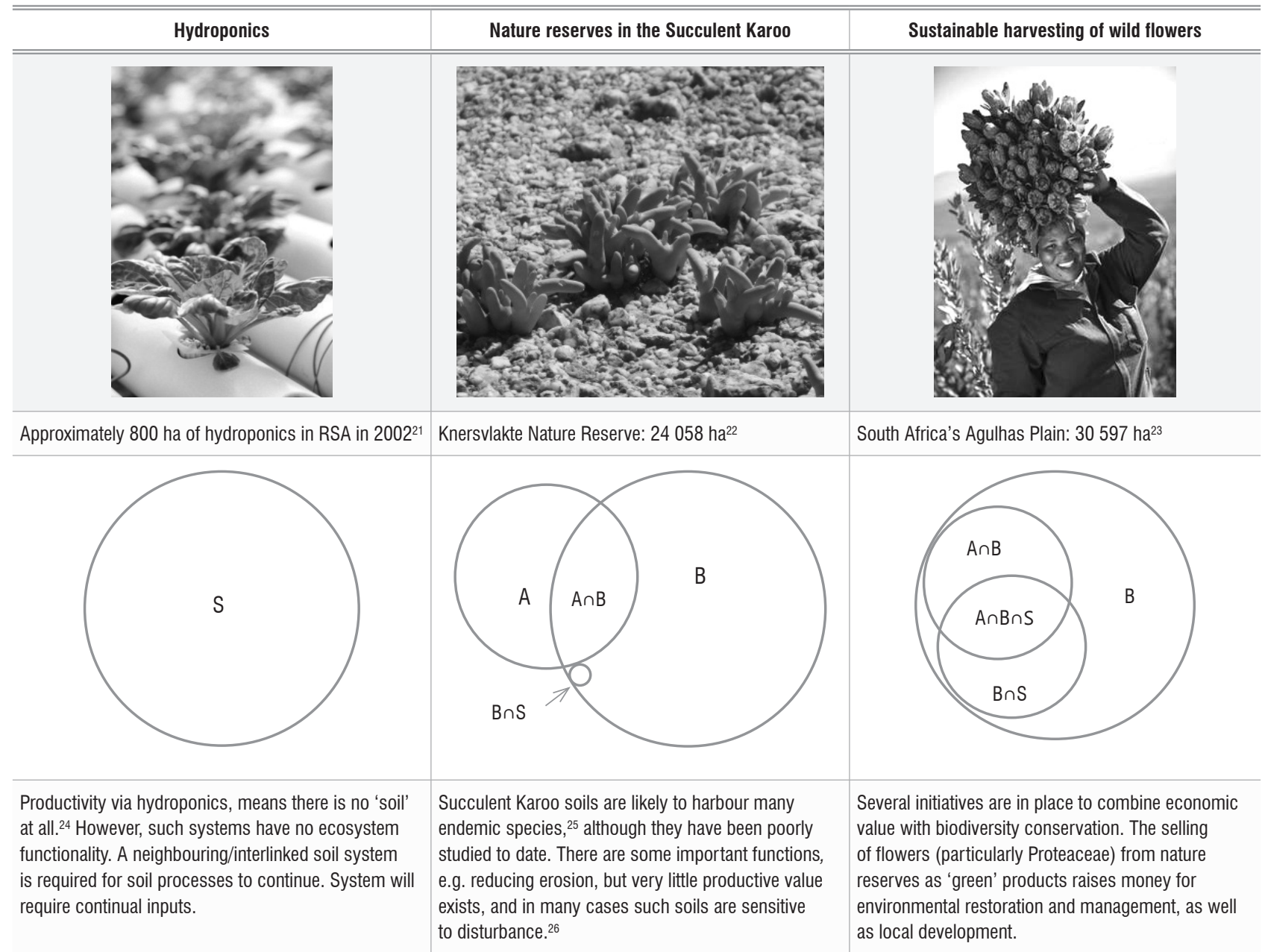

Figure 2: Case studies highlighting how 'soils' differ in abiotic, biotic and socio-economic aspects (based on examples from Figure 1). 
1. What are the underlying interactions and independent values of sustainable agriculture and intensive agriculture $(A \cap B \cap S \& A \cap S)$, taking cognisance that intensive agriculture might not necessarily be unsustainable?

2. What is the human carrying capacity of a functional, healthy soil, irrespective of whether it is used for crop farming or stock farming?

3. How much of soil biodiversity is resistant, or resilient or incompatible with disturbance?

4. How can natural benchmarks for soils in South Africa be determined?

5. Can the interactions within the total system, e.g. those among production systems, soil organisms and water-based soil nutrient cycling, be analysed? Such analysis could include the following:

- Interaction and feedback loops between soil organisms and nutrient cycling.

- Interaction and feedback loops between plants and soil organisms that affect nutrient cycling.

- Interaction and feedback loops between soil nutrient cycling processes and crop yield.

- Identification of soil organisms and their nutrient processing qualities.

- Quantification of nutrient cycles.

- Identification of species assemblages most beneficial to soil processes and crop yield.

One of the first priorities identified by SERG was the need to collate and mobilise data and collections to consolidate and compare the state of knowledge of each group.

\section{Conclusion}

We anticipate that research on soils will be a major initiative linking fundamental and applied research endeavours in the times ahead, especially in the context of climate smart management strategies. Having said this, we do recognise that the establishment of thresholds for biological indicators of soil health is a far greater challenge than the establishment of thresholds for either chemical or physical indicators of soil health, simply because biological indicators are too variable over short periods. Future research endeavours will therefore have to breach this complication.

\section{Acknowledgements}

We thank our respective institutions and departments for support in terms of funding and facilities. We also thank the NRF for funding. An anonymous reviewer is gratefully acknowledged for providing many positive and thought-provoking comments which helped improve the manuscript.

\section{References}

1. Millennium Ecosystem Assessment. Ecosystems and human well-being: Biodiversity synthesis. Washington, DC: World Resource Institute; 2005.

2. Huntley B, Siegfried R, Sunter C. South African environments into the $21 \mathrm{st}$ century. Cape Town: Human and Rousseau and Tafelberg Publishers; 1989.

3. Du Preez CC, Van Huyssteen CW, Mnkeni PNS. Land use and soil organic matter in South Africa 2: A review on the influence of arable crop production. S Afr J Sci. 2011;107(5/6), Art. \#358, 8 pages. http://dx.doi.org/10.4102/ sajs.v107i5/6.358

4. Department of Environmental Affairs. State of the environment: Land [homepage on the Internet]. No date [cited 2013 Oct 14]. Available from: http://soer.deat.gov.za/22.html

5. Driver A, Sink KJ, Nel JN, Holness S, Van Niekerk L, Daniels F, et al. National biodiversity assessment 2011: An assessment of South Africa's biodiversity and ecosystems. Synthesis report. Pretoria: South African National Biodiversity Institute and Department of Environmental Affairs; 2012.

6. Carvalheiro LG, Veldtman R, Shenkute A, Tesfay GB, Pirk CWW, Donaldson JS, et al. Natural and within-farmland biodiversity enhances crop productivity. Ecol Lett. 2011;14:251-259. http://dx.doi.org/10.1111/j.14610248.2010.01579.x
7. Lobry de Bruyn LA, Abbey JA. Characterisation of farmers' soil sense and the implications for on-farm monitoring of soil health. Aust J Exp Agric. 2003;43:285-305. http://dx.doi.org/10.1071/EA00176

8. Gugino BK, Idowu OJ, Schindelbeck RR, Van Es HM, Wolfe DW, Moebius $\mathrm{BN}$, et al. Cornell soil health assessment training manual. New York: Cornell University; 2007.

9. Leverington F, Hockings M, Lemos Costa K. Management effectiveness evaluation in protected areas - a global study. Gatton, Australia: IUCN; 2008.

10. Jones DL, Dennis PG, Owen AG, Van Hees PAW. Organic acid behaviour in soils - misconceptions and knowledge gaps. Plant Soil. 2003;248:31-41. http://dx.doi.org/10.1023/A:1022304332313

11. Balmford A, Green R, Phalan B. What conservationists need to know about farming. Proc R Soc B. 2012;279:2714-2724. http://dx.doi.org/10.1098/ rspb.2012.0515

12. Farina A. Principles and methods in landscape ecology. Towards a science of landscape. Dordrecht: Springer; 2006.

13. Decaëns T, Jiminéz JJ, Gioia C, Measey GJ, Lavelle P. The values of soil animals for conservation biology. Eur J Soil Biol. 2006;42:S23-S38.

14. Huber S, Prokop G, Arrouays D, Banko G, Bispo A, Jones RJA, et al., editors. Environmental assessment of soil for monitoring: Volume I. Indicators \& criteria. EUR $23490 \mathrm{EN} / 1$. Luxembourg: Office for the official publications of the European communities; 2008.

15. Mulder C, Vonk AJ. Nematode traits and environmental constraints in 200 soil systems: Scaling within the $60-6000 \mu \mathrm{m}$ body size range. Ecology. 2011;92:10. http://dx.doi.org/10.1890/11-0546.1

16. Lawrence RF. The biology of the cryptic fauna of forests. With special reference to the indigenous forests of South Africa. Cape Town: Balkema; 1953.

17. Robertson HG. Afrotropical ants (Hymenoptera: Formicidae): Taxonomic progress and estimation of species richness. J Hymenopt Res. 2000;9:71-84.

18. Robertson HG. Revision of the ant genus Streblognathus (Hymenoptera: Formicidae: Ponerinae). Zootaxa. 2002;97:1-16.

19. Parr CL, Robertson HG, Chown SL. Apomyrminae and Aenictogitoninae: Two new subfamilies of ant (Hymenoptera: Formicidae) for southern Africa. Afr Entomol. 2003;11:128-129.

20. Foord SH, Dippenaar-Schoeman AS, Haddad CR. Chapter 8 - South African spider diversity: African perspectives on the conservation of a megadiverse group. In: Grillo 0 , Venora $\mathrm{G}$, editors. Changing diversity in changing environment. Rijeka, Croatia: InTech Publishing; 2011. p. 163-182.

21. Gull C. Study of Pythium root diseases of hydroponically grown crops, with emphasis on lettuce [MSc dissertation]. Pretoria: University of Pretoria; 2002. 
22. Desmet PG. A systematic plan for a protected area system in the Knersvlakte region of Namaqualand. Stellenbosch: World Wildlife Fund; 1999. Available from: www.pcu.uct.ac.za/resources/reports/ipc9901.pdf

23. Conradie B. Farmers' views of landscape initiatives: The case of the Agulhas plain, CFR. Cape Town: Centre for Social Science Research, UCT; 2010. Available from: www.cssr.uct.ac.za/sites/cssr.uct.ac.za/files/pubs/ wp278.pdf
24. Bridgewood L. Hydroponics: Soilless gardening explained. Marlborough, Wiltshire: The Crowood Press; 2003.

25. Cincotta RP, Wisnewski J, Engelman R. Human population in the biodiversity hotspots. Nature. 2000;404:990-992. http://dx.doi.org/10.1038/35010105

26. Brooks TM, Mittermeier RA, Mittermeier CG, Da Fonseca GAB, Rylands AB, Konstant WR, et al. Habitat loss and extinction in the hotspots of biodiversity. Conserv Biol. 2002;16:909-923. http://dx.doi.org/10.1046/j.1523-1739.2002.00530.x 